\title{
Hydraulic and Biochemical Gradients Limit Wetland Mercury Supply to an Adirondack Stream
}

\author{
Paul M. Bradley ${ }^{1 *}$, Douglas A. Burns ${ }^{2}$, Judson W. Harvey ${ }^{3}$, Celeste A. Journey ${ }^{1}$, \\ Mark E. Brigham ${ }^{4}$, Karen Riva-Murray ${ }^{2}$ \\ ${ }^{1}$ United States Geological Survey, Columbia, South Carolina, United States of America \\ ${ }^{2}$ United States Geological Survey, Troy, New York, United States of America \\ ${ }^{3}$ United States Geological Survey, Reston, Virginia, United States of America \\ ${ }^{4}$ United States Geological Survey, Mounds View, Minnesota, United States of America
}

Received: January 05, 2016; Accepted: February 09, 2016; Published: February 22, 2016

*Corresponding author: Paul M. Bradley, E-mail:pbradley@usgs.gov

\begin{abstract}
Net fluxes (change between upstream and downstream margins) for water, methyl mercury (MeHg), total mercury (THg), dissolved organic carbon (DOC), and chloride $(\mathrm{Cl})$ were assessed twice in an Adirondack stream reach (Sixmile Brook, USA), to test the hypothesized importance of wetland-stream hydraulic and chemical gradients as fundamental controls on fluvial mercury ( $\mathrm{Hg}$ ) supply. The $500 \mathrm{~m}$ study reach represented less than $4 \%$ of total upstream basin area. During a snowmelt high-flow event in May 2009surface water, DOC, and chloride fluxes increased by $7.1 \pm 1.3 \%, 8.0 \pm 1.3 \%$, and $9.0 \pm 1.3 \%$, respectively, within the reach, demonstrating that the adjacent wetlands are important sources of water and solutes to the stream. However, shallow groundwater $\mathrm{Hg}$ concentrations lower than in the surface water limited groundwater-surface water $\mathrm{Hg}$ exchange and no significant changes in $\mathrm{Hg}$ (filtered $\mathrm{MeHg}$ and $\mathrm{THg}$ ) fluxes were observed within the reach despite the favorable hydraulic gradient. In August 2009, the lack of significant wetland-stream hydraulic gradient resulted in no net flux of water or solutes $\mathrm{MeHg}$, THg, DOC, or $\mathrm{Cl}$ ) within the reach. The results are consistent with the wetlandHg-source hypothesis and indicate that hydraulic and chemical gradient (direction and magnitude) interactions are fundamental controls on the supply of wetland $\mathrm{Hg}$ to the stream.
\end{abstract}

\section{Introduction}

Identifying methyl mercury (MeHg) source areas and the controls on MeHg supply to streams is an environmental priority due to widely-reported correlations between elevated fluvial-MeHg concentrations and fish-Hg contamination [1-3] , the leading cause of fish consumption advisories in streams throughout the United States (US) [4] and Canada [5]. Strong correlations between wetland area and fluvial $\mathrm{MeHg}$ concentrations [6-8], higher dissolved MeHg concentrations [7,9$11]$ and $\mathrm{Hg}$ methylation rates $[7,12]$ in wetlands compared with adjacent stream habitats, and strong wetland-stream hydrologic connectivity [13-16] support the hypothesis that wetland areas are primary sources of fluvial MeHg in many systems [1,10-12,1719]. This wetland-MeHg-source hypothesis, in turn, predicts that unfavorable wetland-stream hydraulic (water) and chemical (MeHg) gradients may limit fluvial MeHg concentrations and fluxes in the adjacent stream reach.

Sixmile Brook (within Fishing Brook watershed; Adirondack region, USA) and a companion study area, McTier Creek (Atlantic Coastal Plain region, USA) [20] (Figure 1)exhibited elevated MeHg bioaccumulation [21] and downstream increases in fluvial MeHg concentrations and yields [7] (Figure 2). In contrast to the limited temporal variability in $\mathrm{MeHg}$ concentrations (or yields)(Figure 2B; [7] ) and persistent wetland-to-stream MeHg gradients observed in McTier Creek[discussed in detail in 13],Sixmile Brook demonstrated substantial variability in fluvial MeHg concentrations (and fluxes)and in wetland-stream MeHg gradients (Figure 2A; [7] ). To better understand the biogeochemical and hydrological processes that contribute to fluvial $\mathrm{MeHg}$ temporal variability in Sixmile Brook and in other Adirondack streams, two approaches were employed: 1) multivariate regression modeling of the encompassing Fishing Brook watershed[presented in 19] and 2) instantaneous, instream mass flux assessments in a $500 \mathrm{~m}$ study reach. Regression analysis of 43 fixed station samples collected in Fishing Brook downstream of Sixmile Brook during 2007-2009 suggested that seasonal temperature-driven effects on wetland $\mathrm{Hg}$ methylation and stream flow variations during the cold dormant season are principal controls on fluvial $\mathrm{MeHg}$ concentration patterns [19]. Because the lowest fluvial $\mathrm{MeHg}$ concentrations were observed under snowmelt, high-flow conditions, instantaneous wetland-stream hydraulic and biogeochemical gradients were hypothesized to be fundamental controls on MeHg supply in Sixmile Brook. Herein, within-reach changes in the fluxes of water, $\mathrm{MeHg}$, THg, DOC, and chloride as well as lateral (groundwater to surface-water) and vertical (hyporheic-porewater)hydraulic 


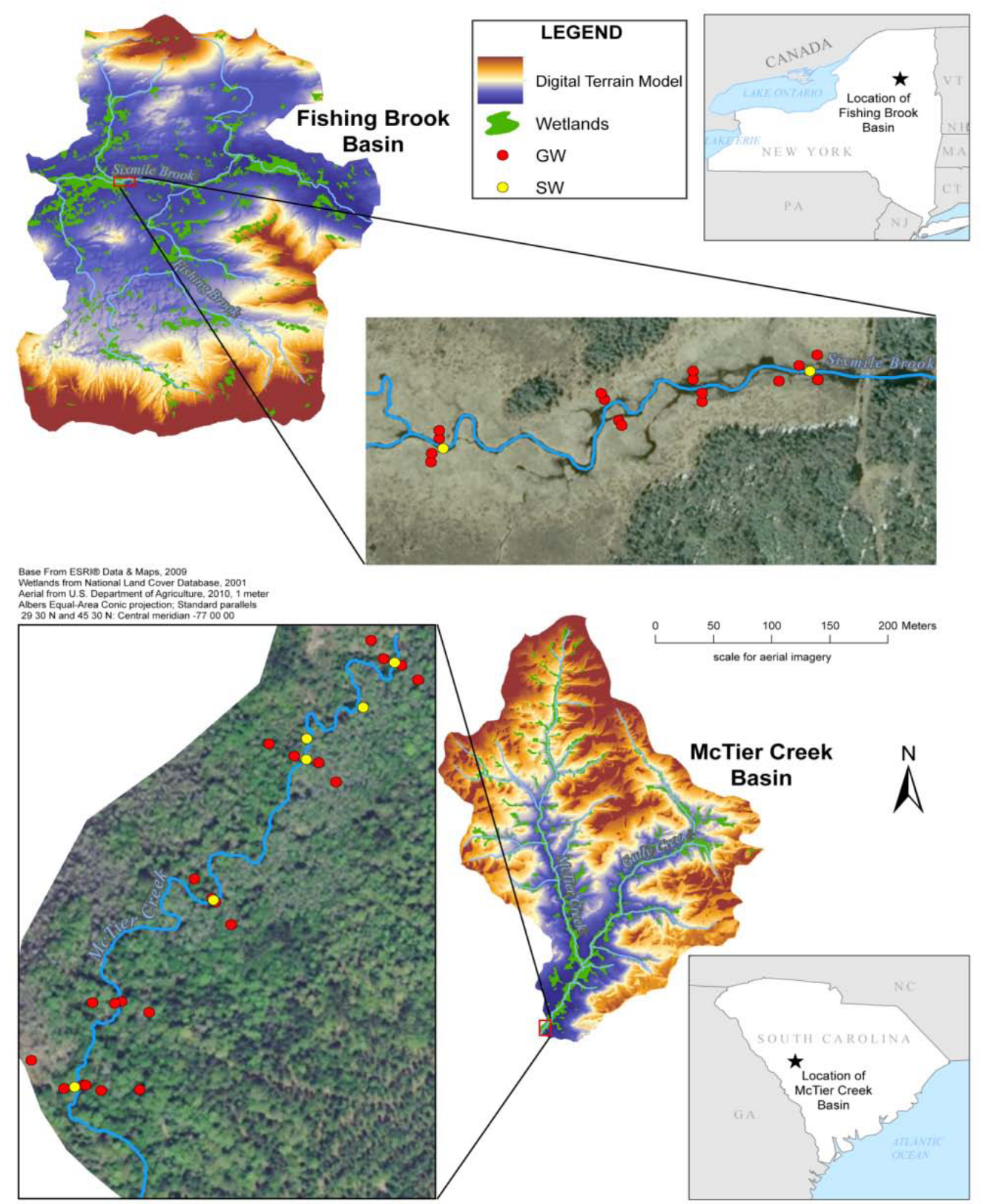

Figure 1: Sixmile Brook and McTier Creek study reaches in the Fishing Brook, New York and McTier Creek, South Carolina basins, respectively. Circles indicate groundwater $(\bullet$, red) and surface-water $(\bullet$, yellow) sampling locations. Basin map colors correspond to Digital Terrain Model elevation gradients from high (brown) to low (blue), with wetland areas shown in green.

and concentration gradients were assessed in Sixmile Brook during snowmelt and later during the growing season, to test the hypothesis that unfavorable hydraulic and chemical gradients (i.e., insignificant or from surface-water toward groundwater) limit fluvial MeHg supply in this and in similar systems in the Adirondacks region.

\section{Material and Methods}

\section{Study Basins}

The Upper Hudson River basin is in the Adirondack region of the Appalachian Highlands of New York [7,20,22,23], where elevated biotic Hg concentrations are reported in lentic systems [21,24-27]. The Sixmile Brook (18 $\mathrm{km}^{2}$ basin area) headwater study basin has been described in detail elsewhere[7,20]. A500 m study reach was established between the upstream confluence with Sixmile Tributary and a downstream hydraulic control (bridge abutment)(Figure 1)[7,20]). The Coastal Plain comparison reach in McTier Creek, South Carolina has been described in detail elsewhere (Figure 1) $[7,13,20]$ ). 


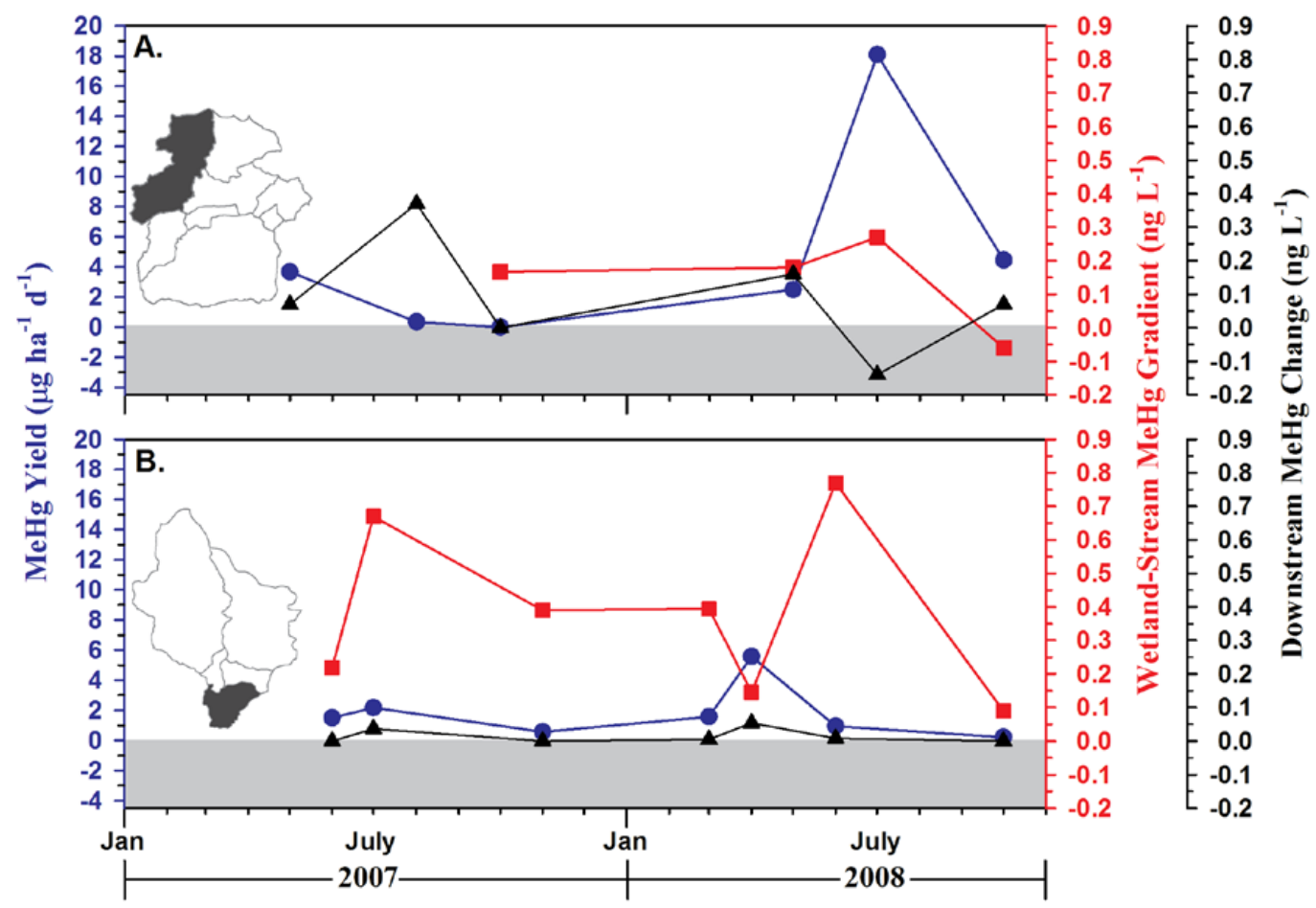

Figure 2: Temporal variations in filtered methylmercury (FMeHg) yields (circles, $\bullet$ ), downstream FMeHg changes (triangles, $\mathbf{\Delta}$ ), and wetland to stream FMeHg concentration gradients (squares, $\boldsymbol{\varpi}$ ) observed in stream segments (black) of Fishing Brook (Sixmile Brook; plot A) and McTier Creek (plot B) basins during 2007-2008. Gray fill indicates negative yields (decrease within stream segment), downstream concentrations changes (decrease between upstream and downstream margins), or wetland-stream concentration gradients (gradient from stream toward wetland).

\section{Piezometer Network}

Out-of-channel (groundwater) piezometers $(2.5 \mathrm{~cm}$ diameter PVC) were installed on both banks with screened intervals 30-60 $\mathrm{cm}$ below land surface (Figure 1; Figures S1 and S2 in File S1). Only data from 20 piezometers closest (3-10 $\mathrm{m}$ ) to the stream channel are discussed in this paper. In-streamhyporheic piezometers (4 each at top and bottom of reach; $1 \mathrm{~cm}$ diameters; $30 \mathrm{~cm}$ screened intervals) were emplaced at the edge of water on each bank and equidistant across the channel with the top of screen set at $20 \mathrm{~cm}$ below the bed sediment/surface-water interface. Fine scale $(1.5$ $\mathrm{cm}$ minimum resolution) vertical solute gradients were assessed at edge-of-water (margin) and center-of-channel (channel)at the downstream reach boundary using two mini-Piezometer (USGS MINIPOINT) devices (seven $0.325 \mathrm{~cm}$ stainless steel tubes, $0.8 \mathrm{~cm}$ screened interval) [28,29]. Each MINIPOINT device was installed with sampling points at approximately 1.5, 4.5, 7.5, 12.5, 17.5, 30, and $60 \mathrm{~cm}$ below the bed-sediment/surface water interface.

\section{Sampling Event Hydrologic Setting}

Lagrangian (following same average parcel of water downstream through the study reach) surface-water flux assessments (described in detail below) were initiatedin2009 during snowmelt in May and during the growing season in August. Lateral solute concentration gradients were assessed by sampling surface water $(0-3 \mathrm{~h}$ from start of sampling), followed immediately by in-channel pore water (3-8 h) and then out- of-channel groundwater (6-34 h). MINIPOINT sampling was conducted during the May assessment.

\section{Stream flow Data Collection}

Instantaneous stream discharge was measured during surface water sampling at a location immediately downstream of the study reach using acoustic Doppler velocimetry (ADV) [22]. Surface-water samples were collected at the mid-time of three consecutive discharge measurements ( $1 \mathrm{~h}$ each). Subsequently, paired Lagrangian discharge measurements were made in triplicate (one h intervals), with upstream and downstream measurements offset by the average downstream transport time ( 25 and $40 \mathrm{~min}$ ) through the reach. Surface-water transport time was calculated using the average stream flow velocity measured immediately downstream of the reach before sample collection.

\section{Water-Quality Data}

For each assessment, triplicate surface-water samples were collected at upstream and downstream boundaries using a Lagrangian sampling approach [13]. Surface-water was collected at one hour intervals at the upstream margin without entering the stream, using a pole to position sample bottles at mid depth in the center of flow until full (Figure S2 in File S1). Corresponding downstream samples were collected following a delay (25 and $40 \mathrm{~min}$ ) equivalent to the average surface-water transport time through the reach. Ultra-trace-level clean-sampling, processing, 
and $\mathrm{Hg}$ analysis procedures were as in $[6,9,30,31]$. Filtered $(0.7$ $\mu \mathrm{m}$ quartz-fiber filter) samples were analyzed for FMeHg by gas chromatographic separation with cold vapor atomic fluorescence spectrometry [32] and for FTHg by oxidation, purge and trap, and cold vapor atomic fluorescence spectrometry [33] at the USGS Mercury Research Laboratory (Middleton, Wisconsin). The reporting limit for FMeHg and FTHg was $0.04 \mathrm{ng} / \mathrm{L}$. Concentrations of DOC [34] and chloride [35]were determined as cited.

Vertical hydraulic gradients in the stream channel at the time of sample collection were estimated as the potentiometric difference between hyporheic pore water (water level inside in-channel piezometers) and surface water (water level outside the piezometers) using an electric water level tape. Porewater samples were collected from in-channel piezometers using a peristaltic pump (flow less than $50 \mathrm{~mL} \mathrm{~min}^{-1}$ ) and low volume (200 $\mathrm{mL}$ purge; $1 \mathrm{~L}$ total pumped volume) sampling techniques [13]. An assessment of water quality parameters $(\mathrm{pH}$, conductivity, and temperature) over time was conducted to verify stream-water entrainment did not occur under these pumping conditions [13]. Out-of-channel groundwater wells were purged (3 well volumes) on day 1 , immediately after water-elevation measurements. Groundwater was sampled and processed as described for in-channel porewater samples. Ultra-low-flow (approximately $2 \mathrm{~mL} \mathrm{~min}^{-1}$ ) MINIPOINT sampling was conducted [as described in detail elsewhere 28] to collect porewater from the shallow hyporheic-flow and underlying groundwaterhyporheic porewater mixing zones using a peristaltic pump. All samples were filtered and preserved with $6.5 \mathrm{~N}$ trace-metal grade $\mathrm{HCl}$ in the field in a temporary glove box[13](Figure S3 in File S1), stored on ice, and shipped overnight to the lab. Fresh gloves, glove-box bags, and pre-cleaned filter assemblies were used for each sample. Peristaltic tubing was acid cleaned (ultrapure $5 \% \mathrm{HCl}$ ) and rinsed (distilled water) between samples [6, 13, 31]. Additional sampling details provided in File S1.

Quality control (QC) samples (15\% of samples) for FTHg included field/method blanks (generally less than $5 \%$ of environmental sample concentrations, less than $10 \%$ in all cases), duplicate analyses (relative percent difference $=4.4 \%$ ), matrix spikes (recovery $=99.0 \% \pm 7.3 \%$ ) and check samples. Corresponding FMeHg QC samples included field/method blanks (less than detection in all cases), duplicate analyses (relative percent difference $=4.6 \%$ ), matrix spikes (recovery $=97.1 \% \pm$ $21.6 \%$ ) and check samples.

\section{Statistical Analyses and Interpretive Framework}

Statistical significance metrics and percentage reach flux increases provided direct, quantitative measures of the importance of reach wetlands as sources of water and solutes to the aquatic habitat during each $3 \mathrm{~h}$ surface-water flux assessment. Reach discharge results were then combined with hyporheic zone hydraulic gradient data to assess the relative importance of advective and diffusive wetland-stream solute exchange. Solute concentration gradients (e.g., groundwater to surface water, in-channel porewater to surface water) clarified the effect of groundwater discharge (dilution or concentration of solutes) on stream solute concentrations and provided insight into the direction and magnitude of diffusive exchange in the event that groundwater discharge was insignificant.

The One-tailed paired t-test was employed to assess flux differences between the top and bottom of the study reach. Kruskal-Wallis ANOVA on Ranks was combined with Dunn's Multiple Comparison Method to identify significant differences between four lateral gradient groups: groundwater, porewater at the channel margin, porewater at the center of channel, and stream surface water. A significance level $(\alpha)$ of 0.05 was employed for all comparisons.

\section{Results and Discussion}

The demonstrated importance of wetland areas as sources of MeHg and $\mathrm{THg}$ to the stream and the substantial temporal variability in MeHg supply to the stream during 2007-2008 (Figure 2; [7] )indicated that Sixmile Brook was a suitable location to evaluate wetland-stream hydraulic and chemical gradients as controls on short-term wetland-stream solute transport under different hydrologic and geochemical conditions. These short (25 and 40min per Lagrangian sample pair, approximately 3 $\mathrm{h}$ total) reach synoptics were intended to rigorously assess "instantaneous" gradients and wetland-stream fluxes and were not intended to represent longer-term wetland-stream dynamics[assessed previously in 7].

\section{Change in Sixmile Brook Reach Fluxes}

During May 2009 snowmelt event, a significant $(\mathrm{p}<0.005)$ increase in stream discharge of $7.1 \pm 1.3 \%$ was observed within the Sixmile Brook study reach (Table 1). Because no tributaries existed within the reach, increases in discharge between upstream and downstream measurements were attributed to groundwater fluxes. Comparable $(8.0 \pm 1.3 \%$ and $9.0 \pm 1.3 \%)$ significant $(\mathrm{p}<0.005)$ increases in the fluxes of DOC and dissolved chloride (respectively) were also observed within the reach, demonstrating efficient hydrologic transport of dissolved constituents from wetland sediments to the stream habitat. However, no statistically significant $(p>0.16)$ changes in the fluxes of FMeHg or FTHg were observed, demonstrating that discharging groundwater was not a significant source of Hg within the study reach during this short surface-water flux assessment. Because significant increases in fluxes of water, DOC, and chloride within the 25 min downstream travel time indicated good wetland-stream hydrologic connectivity and a favorable hydraulic gradient, the lack of significant net fluxes of FMeHg and FTHg was hypothesized to be due to dilute Hg concentrations in groundwater discharge within the study reach during the May assessment.

During the August 2009 growing-season assessment, no statistically significant changes in discharge or in the fluxes of FMeHg, FTHg, DOC or chloride were observed in the Sixmile Brook study reach, indicating that the adjacent riparian wetlands were not a significant source to the reach aquatic habitat during the 40 min downstream travel time(Table 1).During this 
sampling event, however, the apparent lack of net exchange of $\mathrm{Hg}$ and other solutes was attributed to insignificant advective transport between shallow groundwater and the stream. Because the results of the May flux assessment demonstrated good wetland-stream hydrologic connectivity within the reach, the lack of net groundwater discharge during the August event was hypothesized to be due to insignificant wetland-stream hydraulic gradient. In the absence of substantial net hydrologic transport to the stream, solute exchange would be limited to hyporheic zone mixing and diffusive processes at the sediment/surface-water interface, with minimal contribution to reach fluvial chemistry during the approximate 40 minute surface-water travel time between upstream and downstream reach boundaries. The lack of significant change in DOC and dissolved chloride in the absence of an increase in discharge corroborates the previous conclusion that DOC and chloride flux increases observed in May 2009 were attributable to groundwater discharge within the Sixmile reach.

The Sixmile study reach represented less than $4 \%$ of the total upstream basin area[20].The influx of upstream surface-water was the primary (generally greater than $90 \%$ ) source of water and solutes (FMeHg, FTHg, DOC, and chloride) to the study reach for both flux assessment events. The mean percentage increases (7-9\%) in fluxes of surface water, DOC, and chloride observed in the study reach in May 2009, however, were approximately two times greater than the corresponding increase in basin area, indicating that the riparian wetlands within the reach were important sources of water and solutes to the stream habitat. In August 2009, the flux of water and solutes at the downstream margin of the study reach was entirely attributable to surfacewater influx at the upstream margin, demonstrating that contributions from discrete wetland areas vary substantially over time. There was no evidence of significant supply of FMeHg or FTHg from the adjacent wetlands to the aquatic habitat of the Sixmile Brook study reach (Table 1) during either flux assessment, despite the spatial extent of the riparian wetlands bordering the reach (Figure 1) and the potential for solute exchange (DOC and chloride) demonstrated during May (Table 1, Figure 3A3D).The elevated concentrations of $\mathrm{MeHg}$ observed in several wetland piezometers (compared with hyporheic piezometers at channel margins, see Figures 3A and [7] ) and the observed fluvial transport of $\mathrm{MeHg}$ from wetland-dominated reaches upstream in Sixmile Brook are consistent with wetland areas as primary sources of $\mathrm{MeHg}$ to the stream throughout the growing season (Figures $2 \mathrm{~A}$ and $3 \mathrm{~A},[7]$ ). The current results verify the substantial temporal variability in wetland-stream MeHg supply reported previously (Figure 2) [7] and indicate the importance of wetland-stream hydraulic and chemical gradients as important contributors to temporal variability.

The Sixmile Brook flux results are in marked contrast to the consistent, significant ( $p<0.0001$ ) increases (generally 10 $\%$ or more) in both water and dissolved constituents (FMeHg, FTHg, DOC, chloride) previously reported in sister study area at McTier Creek during two 2009 sampling events(Table1; [13]). To better understand the comparative lack of net FMeHg and FTHg exchange between the adjacent riparian wetlands and the aquatic habitat within the Sixmile Brook study reach during the 2009, surface-water flux assessments, geochemical gradients between the wetland and the stream channel, as well as stream channel vertical hydraulic gradients were assessed.

\section{Groundwater to Surface Water Gradients}

Differences in solute concentrations between surface water samples and samples of groundwater collected from wetland piezometers (located 3-10 m from the stream bank) were evaluated to assess the potential importance of shallow wetland groundwater as a longer-term source of solutes to the stream. Results from piezometers installed across the stream channel at the upstream and downstream reach boundaries were used to assess the potential importance of groundwater discharge as a proximal source of solutes to the stream at the time of sample collection. Piezometers emplaced at the channel margins provided insight into the importance of shallow wetland groundwater discharge to the stream, while piezometers placed near the center of the channel reflected the contribution of comparatively deeper groundwater [13].

During May 2009, net positive (toward surface water compartment) vertical hydraulic gradients ranging from 0.025 0.05 (0.5-1.0 cm water level change over $20 \mathrm{~cm}$ distance; data not shown) were observed in piezometers at the channel margins of Sixmile Brook, consistent with ongoing discharge of shallow wetland groundwater to the stream and the observed

Table 1: Change (\%) in mass fluxes (means \pm standard deviations; $n=3$ ) of water and solutesbetween upstream and downstream margins of the Sixmile Brook (NY) and McTier Creek (SC) study reaches during 2009.Negative values indicatea net decrease andp-values in bold are statistically significant (one-tailed paired t-test; $\mathrm{p}<0.05$ ).

\begin{tabular}{|c|c|c|c|c|c|c|c|}
\hline Reach & Event & Metric & Water & FMeHg & FTHg & DOC & Chloride \\
\hline Sixmile Brook & May & change (\%) & $7.1 \pm 1.3$ & $0.4 \pm 1.2$ & $-0.9 \pm 1.2$ & $8.0 \pm 1.3$ & $9.0 \pm 1.3$ \\
\hline & & p-value & $\mathbf{0 . 0 0 5}$ & 0.317 & 0.162 & $\mathbf{0 . 0 0 4}$ & $\mathbf{0 . 0 0 3}$ \\
\hline & August & change (\%) & $4.9 \pm 6.9$ & $-7.0 \pm 5.8$ & $0.1 \pm 6.2$ & $-4.7 \pm 5.9$ & $-3.9 \pm 5.9$ \\
\hline & & p-value & 0.158 & 0.086 & 0.496 & 0.148 & 0.183 \\
\hline \multirow{2}{*}{ McTierCreek } & April & change (\%) & $10.3 \pm 0.1$ & $27.6 \pm 0.2$ & $9.4 \pm 0.1$ & $13.0 \pm 0.1$ & $7.8 \pm 0.1$ \\
\hline & & p-value & $<\mathbf{0 . 0 0 0 1}$ & $<\mathbf{0 . 0 0 0 1}$ & $<\mathbf{0 . 0 0 0 1}$ & $<\mathbf{0 . 0 0 0 1}$ & $<\mathbf{0 . 0 0 0 1}$ \\
\hline & July & change (\%) & $10.8 \pm 0.3$ & $23.1 \pm 0.3$ & $14.7 \pm 0.3$ & $13.5 \pm 0.3$ & $8.3 \pm 0.3$ \\
\hline & & p-value & $<\mathbf{0 . 0 0 0 1}$ & $<\mathbf{0 . 0 0 0 1}$ & $<\mathbf{0 . 0 0 0 1}$ & $<\mathbf{0 . 0 0 0 1}$ & $<\mathbf{0 . 0 0 0 1}$ \\
\hline
\end{tabular}


significant increase in surface-water flux within the reach. No vertical hydraulic gradients were detectable (potential difference less than $2 \mathrm{~mm}$ ) in piezometers located in the center of the channel. Concentrations of DOC and chloride in channel margin piezometers were comparable to those observed in surface water, consistent with the significant increases in DOC and chloride fluxes within the study reach (Figure 3C \&3D). In contrast, FMeHg concentrations (Figure $3 \mathrm{~A}$ ) in channel margin piezometers were significantly $(t$-test; $\mathrm{p}<0.0001$ ) less than in surface water (mean concentration approximately 15\% of mean surface water concentration), consistent with the lack of detectable change in FMeHg flux within the reach (Table 1). Similarly, FTHg concentrations (Figure 3B) in channel margin piezometers were significantly ( $t$-test; $\mathrm{p}=0.003$ ) less than in surface water (mean channel margin concentration approximately half of mean surface water concentration), consistent with the lack of significant change in FTHg flux within the reach during the May event (Table 1). It is noteworthy that surface-water FMeHg and FTHg concentrations were within the range (not statistically different; Kruskal-Wallis One-Way ANOVA on ranks; $p>0.05$ ) observed in groundwater piezometers located 3-10 m from the stream channel (Figure 3A \&3B), indicating that shallow groundwater was an important source of FMeHg and FTHg to the stream over longer time periods. However, the low concentrations of FMeHg and FTHg observed in channel margin piezometers indicated that dilute-Hg groundwater was discharging to the stream reach during the May stream-water flux assessment.

No vertical hydraulic gradients were detected in stream piezometers (margin or center of channel) during August 2009 (data not shown), suggesting minimal groundwater discharge and consistent with the lack of significant change in the fluxes of water, FMeHg, FTHg, DOC, or chloride within the Sixmile Brook reach. No significant differences in DOC concentrations were observed between groundwater, hyporheic porewater, and surface water (Figure 3G), indicating the potential for groundwater as a substantial source of DOC to the stream under favorable hydrologic conditions. Combined with the lack of significant change in discharge within the reach, this result demonstrates that the lack of increased DOC flux within the study reach was due to little or no hydraulic gradient and a corresponding lack of advective hydrologic transport from wetlands to the stream. In contrast, concentrations of FMeHg, FTHg, and chloride were statistically significantly higher in surface water than in groundwater or porewater. The lack of significant changes in fluxes within the reach, the lack of detectable vertical hydraulic gradients, and lower concentrations in groundwater than surface water indicated that the extensive riparian wetlands within the reach were not a significant source of $\mathrm{Hg}$ to the stream reach during the short August 2009 streamwater flux assessment period.

In contrast to Sixmile Brook, concentrations of FMeHg, FTHg, DOC, and chloride in groundwater and in-channel pore water piezometer samples were comparable to or greater than observed in surface-water samples at McTier Creek (Figure 4A4D), consistent with groundwater as a substantial source of these solutes to the stream habitat under the favorable hydrologic
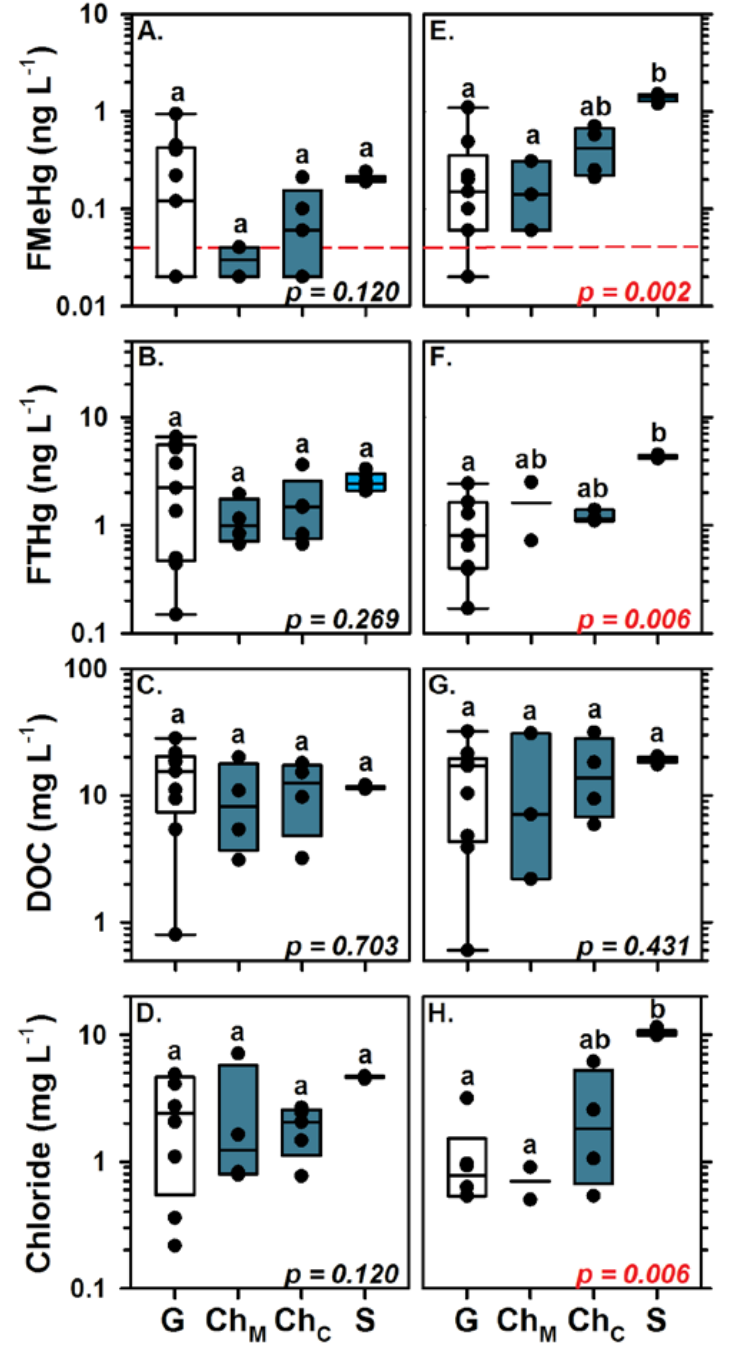

(9) (4) (5) (6)

(9) (3) (4) (6)

Figure 3: Concentrations of filtered methylmercury (A, E), filtered total mercury (B, F), dissolved organic carbon $(\mathrm{C}, \mathrm{G})$, and dissolved chloride (D, H) at Sixmile Brook in May (A-D) and August (E-H) 2009. Boxplots are groundwater $(\mathrm{G})$ collected from wells $3-10 \mathrm{~m}$ from stream bank, porewater collected from the margin $\left(\mathrm{Ch}_{\mathrm{M}}\right)$ and center $\left(\mathrm{Ch}_{\mathrm{C}}\right)$ of the channel, and stream water (S)(number of samples in parentheses). Dashed red line is the FMeHg reporting limit of $0.04 \mathrm{ng} \mathrm{L}^{-1}$. Censored data were set at $0.02 \mathrm{ng} \mathrm{L}^{-1}$. Boxes, centerlines, whiskers, and circles $(\bullet)$ indicate interquartile ranges, medians, $10^{\text {th }}$ and $90^{\text {th }}$ percentiles, and data, respectively. Different letters indicate statistically different groups $(\mathrm{p}<0.05)$.

conditions observed in this study. Mass balance calculations and water-stable-isotope mixing results indicated that $80 \%$ or more of the observed increases in discharge and solute fluxes within the McTier Creek study reach were attributable to groundwater discharge [13].

\section{Hyporheic Vertical Profiles}

MINIPOINT vertical concentration profiles obtained from the margin and center of the Sixmile Brook stream channel 

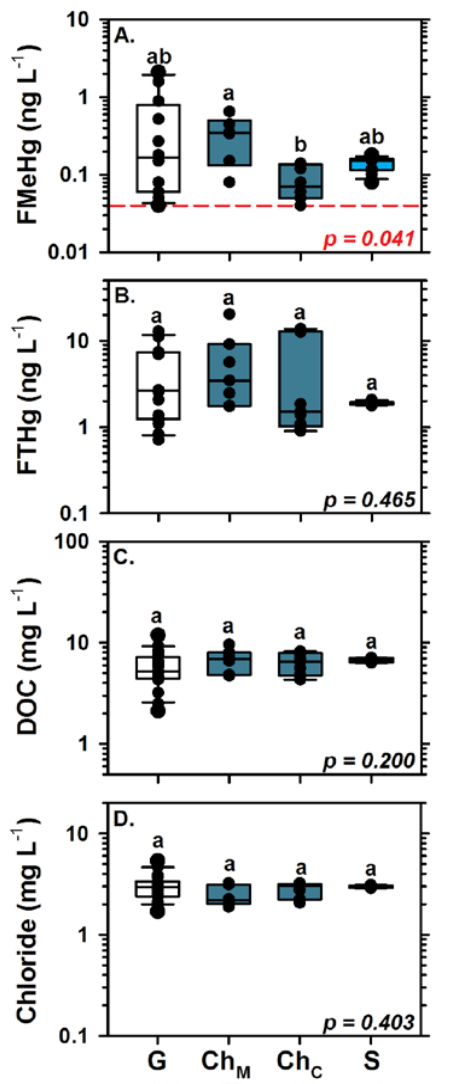

(19) (7) (9) (12)

Figure 4: Concentrations of filtered methylmercury (A), filtered total mercury (B), dissolved organic carbon (C), and dissolved chloride (D) at McTier Creek (April and July data did not differ significantly and are combined) in 2009. Other labeling as in Figure 3.

during May provided additional insight into the supply of solutes to the stream reach (Figure 5A-D). Because MINIPOINT assessments were conducted once and thus lacked estimates of sample variability, these concentration profiles were used only to 1)assess centimeter-scale trends in vertical hyporheic concentration gradients, 2) identify the depth of the surface-water mixing (hyporheic flow) zone, and 3) verify relative differences in chemical signatures in shallow groundwater samples collected at the channel margin and comparatively deeper groundwater samples collected from the channel center.

Chloride profiles indicated a well-mixed hyporheic-flow porewater layer (indistinguishable from surface water to a depth of approximately $20 \mathrm{~cm}$ below the sediment/surface water interface) and decreasing concentrations with increasing depth from 20-60 cm (Figure 5D). FMeHg, FTHg, and DOC concentrations also generally decreased with increasing depth, consistent with the previous conclusion that the primary source of these solutes to the stream reach was upstream surface water. The fact that channel margin, porewater FMeHg and FTHg concentrations below the surface mixed (hyporheic flow) layer were approximately an order of magnitude less than in the overlying surface water is consistent with the discharge of deeper groundwater with dilute $\mathrm{Hg}$ and the lack of significant change in FMeHg and FTHg fluxes within the study reach during the May event. The fact that concentration profiles from the margin and center of the channel were comparable for the conservative chloride ion (Figure 5D) as well as for FTHg and DOC (Figure 4AC) is also consistent with surface water as the primary control on these shallow, hyporheic-porewater concentrations during the May flux assessment. However, concentrations of FMeHg in the hyporheic $(0-20 \mathrm{~cm})$ zone were generally higher at the channel margin than at the channel center (Figure 5A), consistent with previous conclusions that wetlands are longer-term sources of FMeHg to Sixmile Brook [7].
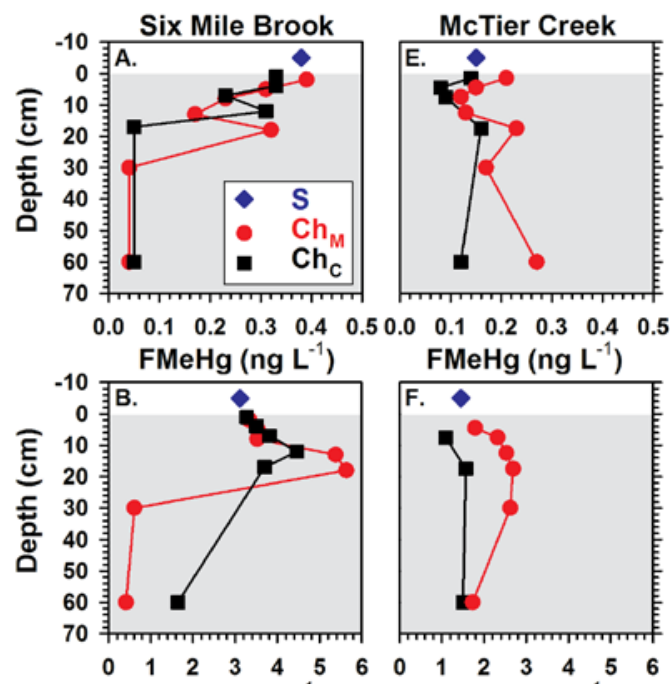

FMeHg (ng L $\left.{ }^{-1}\right)$
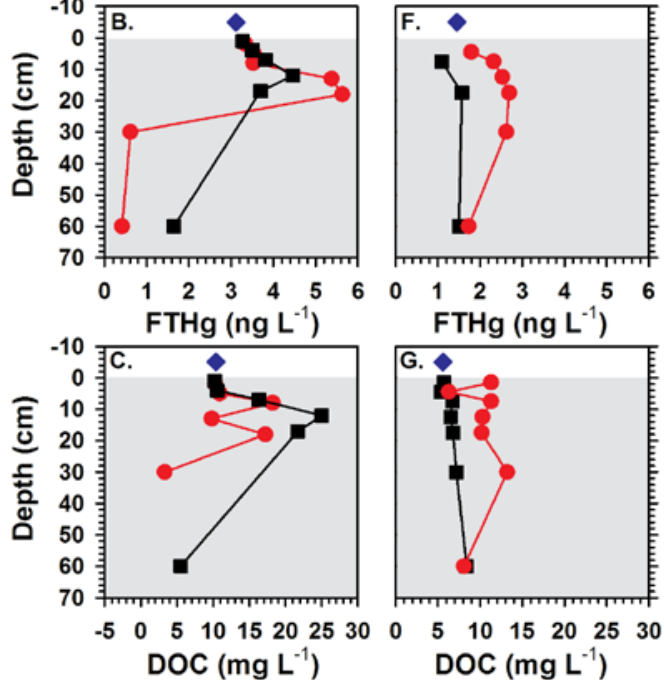

FTHg (ng L $\left.{ }^{-1}\right)$

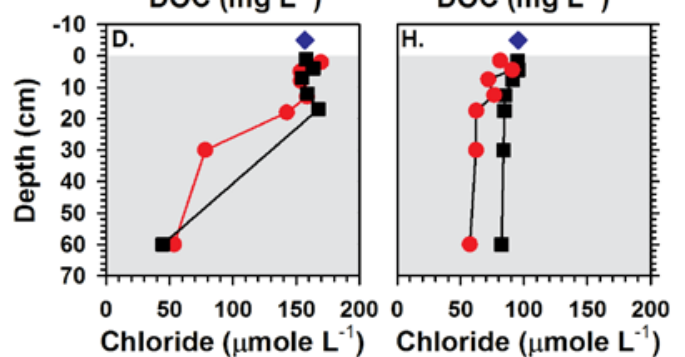

Figure 5: Vertical gradients in hyporheic-pore-water concentrations of filtered methylmercury (A, E), filtered total mercury (B, F), dissolved organic carbon $(C, G)$, and chloride $(D, H)$ at the downstream margins of Sixmile Brook (A-D; June 2009) and McTier Creek (E-H; July 2009). Circles $(\bullet)$, squares $(\bullet)$, and diamonds $(\bullet)$ indicate channel margin and center porewater and surface water, respectively. 
In contrast, only limited changes in concentrations with depth were observed in MINIPOINT samples from McTier Creek in July 2009, and solute concentrations in porewater and surfacewater samples were comparable (Figure $5 \mathrm{E}-\mathrm{H}$ ). These results are in agreement with the documented importance of groundwater discharge in the McTier Creek study reach [13] under nonflood conditions. FMeHg, FTHg, and DOC concentrations were consistently higher at the channel margin than at the center of channel, further supporting the conclusion that discharge of shallow groundwater from adjacent wetland/riparian floodplain areas is the primary source of these constituents to the stream. In contrast, chloride concentrations were consistently higher at the center channel location than at the channel margin and comparable to surface-water concentrations, indicating that the primary sources of chloride in the reach were surface water from upstream of the reach and discharge of deeper groundwater within the reach. The fact that surface-water concentrations of FMeHg, FTHg, and DOC were intermediate to MINIPOINT concentrations from the margin and center locations (Figure 5E$5 G$ ) is consistent with the single-screen in-channel Piezometer results (Figure 4A-4C) and indicates that surface water in the stream reach is a mixture of shallow and comparatively deeper groundwater discharge.

\section{Implications for MeHg Supply}

The results of this study verify that the extensive riparian wetlands that border Sixmile Brook are hydrologically well connected to the stream. Consequently, the results are compatible with the earlier conclusion that adjacent and upstream wetland areas are important long-term sources of water and solutes to the Sixmile Brook aquatic environment [7]. These results also support the hypothesis that unfavorable instantaneous wetland-stream hydraulic and chemical gradients (direction and magnitude) limit the importance of these wetland areas as sources of $\mathrm{Hg}$ and other solutes to Adirondacks-region stream habitats in the short term.

Hg-risk management strategies are applied at regional to national scales, while foundational research on environmental $\mathrm{Hg}$ processes and dynamics is most often conducted at focused-reach to small-watershed scales. The development of mechanistic models that extend research-scale findings to $\mathrm{Hg}$ risk-management scales is challenged by competing needs to capture those $\mathrm{Hg}$ processes which are most essential to system simulation while maintaining model usability (i.e., avoiding parameter inflation and excessive processing time). Numerical model improvements that allow more accurate prediction of temporal and spatial variations in fluvial MeHg supply are needed to better manage Hg-bioaccumulation risk in the Adirondacks and other regions of North America $[19,36]$. The current results suggest that continued investigation of factors that affect temporal variations in wetland-stream gradients and improved near-stream hydrologic models may substantially improve Hgrisk-management models.

\section{Acknowledgements}

The U.S. Geological Survey National Water Quality Assessment and Toxic Substances Hydrology Programs supported this research. We thank Finch-Pruyn and the Nature Conservancy as well as the family of Senator Strom Thurmond for access to the SixmileBrook and McTier Creek study reaches, respectively.

\section{Data Availability}

Data in Figures 2-4 can be downloaded from the USGS National Water Information System (NWIS) at (http://dx.doi. org/10.5066/F7P55KJN). Data in Figure 5 are available at (http://dx.doi.org/10.5066/F7QN64TC).

\section{References}

1. Ward D, Nislow K, Folt C. Bioaccumulation syndrome: identifying factors that make some stream food webs prone to elevated mercury bioaccumulation. Annals of the New York Academy of Sciences. 2010;1195:62-83. doi: 10.1111/j.1749-6632.2010.05456.x.

2. Chasar L, Scudder B, Stewart A, Bell A, Aiken G. Mercury cycling in stream ecosystems. 3. Trophic dynamics and methylmercury bioaccumulation. Environmental Science and Technology. 2009; 15;43(8):2733-2739.

3. Riva-Murray K, Bradley PM, Scudder Eikenberry BC, Knightes CD, Journey CA, Mark E. Brigham, et al. Optimizing Stream Water Mercury Sampling for Calculation of Fish Bioaccumulation Factors. Environmental science \& technology. 2013;47(11):5904-5912. DOI: $10.1021 / \mathrm{es} 303758 \mathrm{e}$

4. U.S. Environmental Protection Agency (2011) 2010 Biennial National Listing of Fish Advisories. U.S. Environmental Protection Agency. EPA820-F-11-014 EPA-820-F-11-014. 7 p.

5. Canada E (2011) Fish Consumption Advisories. Environment and Health Concerns: Environment Canada.

6. Brigham ME, Wentz DA, Aiken GR, Krabbenhoft DP. Mercury cycling in stream ecosystems. 1. Water column chemistry and transport. Environmental Science and Technology. 2009;43(8):2720-2725. DOI: $10.1021 /$ es802694n

7. Bradley P, Burns D, Murray K, Brigham M, Button D, Chasar LC et al. Spatial and seasonal variability of dissolved methylmercury in two stream basins in the eastern United States. Environmental Science and Technology 2011;45(6):2048-2055. doi: 10.1021/es103923j.

8. Glover J, Domino M, Altman K, Dillman J, Castleberry W, Eidson JP et al. Mercury in South Carolina Fishes, USA. Ecotoxicology. 2010;19(4):781-795. doi: 10.1007/s10646-009-0455-6.

9. Bradley P, Journey CA, Chapelle F, Lowery M, Conrads P. Flood Hydrology and Methylmercury Availability in Coastal Plain Rivers. Environmental Science \& Technology. 2010;44(24):9285-9290. doi: 10.1021/es102917j.

10. St. Louis VL, Rudd JWM, Kelly C, Beaty KG, Bloom NS, Nicholas S. Bloom, et al. Importance of wetlands as sources of methyl mercury to boreal forest ecosystems. Canadian Journal of Fisheries and Aquatic Sciences. 1994;51(5): 1065-1076.

11. St. Louis VL, Rudd JWM, Kelly C, Beaty KG, Flett RJ, Nigel T. Roulet et al. Production and loss of methylmercury and loss of total mercury from boreal forest catchments containing different types of wetlands. Environmental Science and Technology. 1996;30:(9):2719-2729. DOI: $10.1021 /$ es950856h.

12. Marvin-DiPasquale M, Lutz MA, Brigham ME, Krabbenhoft DP, Aiken GR, Orem WH, et al. Mercury cycling in stream ecosystems. 2. Benthic 
methylmercury production and bed sediment-pore water partitioning Environmental Science and Technology. 2009;43:(8):2726-2732.

13. Bradley P, Journey C, Lowery M, Brigham M, Burns D, Button DTet al. Shallow groundwater mercury supply in a Coastal Plain stream. Environmental Science and Technology. 2012;46(14):7503-7511. doi: $10.1021 / \mathrm{es} 301540 \mathrm{~g}$

14. Branfireun BA, Roulet NT. Controls on the fate and transport of methylmercury in a boreal headwater catchment, northwestern Ontario, Canada. Hydrology and Earth System Sciences. 2002;6(4):783794

15. Devito KJ, Waddington JM, Branfireun BA. Flow reversals in peatlands influenced by local groundwater systems. Hydrologica Processes.1997;11(1):103-110. DOI: 10.1002/(SICI)10991085(199701)11:1<103::AID-HYP417>3.0.CO;2-E.

16. Galloway ME, Branfireun BA. Mercury dynamics of a temperate forested wetland. Science of the Total Environment. 2004;325(13):239-254.

17. Warner KA, Bonzongo J-CJ, Roden EE, Ward GM, Green AC, Chaubey I, et al. Effect of watershed parameters on mercury distribution in different environmental compartments in the Mobile Alabama River Basin, USA. Science of the Total Environment. 2005;347(1-3):187207.

18. Rypel AL, Arrington DA, Findlay RH. Mercury in Southeastern U.S Riverine Fish Populations Linked to Water Body Type. Environmental Science and Technology. 2008;42(14):5118-5124.

19. Burns D, Nystrom E, Wolock D, Bradley P, Riva Murray K. An empirical approach to modeling methylmercury concentrations in an Adirondack stream watershed. Journal Geophysical Research Biogeosciences 2014;119:1970-1984.

20. Scudder Eikenberry B, Riva-Murray K, Smith M, Bradley P, Button D, Jimmy $\mathrm{M}$ et al. Environmental settings of selected streams sampled for mercury in New York and South Carolina, 2005-09. U.S. Geological Survey. 2012;36 p.

21. Riva Murray K, Chasar L, Bradley P, Burns D, Brigham M, Smith MJ, et al. Spatial patterns of mercury in macroinvertebrates and fishes from streams of two contrasting forested landscapes in the eastern United States. Ecotoxicology. 2011;20(7):1530-1542. doi: 10.1007/s10646011-0719-9.

22. Levesque V, Oberg K. Computing discharge using the index velocity method. US Geological Survey Techniques and Methods. 2012;3-A23:148P.

23. Vigil JFP, R.J.; Howell, D.G. A tapestry of time and terrain. US Geological Survey Geologic Investigations Series 2720. 2000.

24. Driscoll CT, Han Y-J, Chen CY, Evers DC, Lambert KF, Thomas M. Holsen, et al. Mercury Contamination in Forest and Freshwater Ecosystems in the Northeastern United States. BioScience. 2007;57(1):17-28. DOI: http://dx.doi.org/10.1641/B570106.

25. Evers DC, Han YJ, Driscoll CT, Kamman NC, Goodale MW, THOMAS M
HOLSEN et al. Biological mercury hotspots in the northeastern United States and southeastern Canada. BioScience. 2007;57(1):29-43.

26. Yeardley Jr RB, Lazorchak JM, Paulsen SG . Elemental Fish Tissue Contamination in Northeastern U.S. Lakes: Evaluation of an Approach to Regional Assessment. Environmental toxicology and chemistry. 1998;17(9):1875-1884. DOI: 10.1002 /etc.5620170931

27. Ullrich M, Tanton TW, Abdrashitova SA. Mercury in the Aquatic Environment: A Review of Factors Affecting Methylation. Critical Reviews in Environmental Science and Technology. 2001;31(3):241293.

28. Harvey JW, Fuller CC. Effect of enhanced manganese oxidation in the hyporheic zone on basin-scale geochemical mass balance. Water Resources Research. 1998;34(4):623-636.

29. Duff JH, Murphy F, Fuller CC, Triska FJ, Harvey JW, et al. A mini drivepoint sampler for measuring pore water solute concentrations in the hyporheic zone of sand-bottom streams. Limnology and Oceanography. 1998;43(6)1378-1383. DOI: 10.4319/ lo.1998.43.6.1378

30. Fitzgerald WF, Watras CJ. Mercury in surficial waters of rural Wisconsin lakes. The Science of Total Environment. 1989;87(88):223232. doi:10.1016/0048-9697(89)90237-4.

31. Lewis ME, Brigham ME (2004) National field manual for the collection of water-quality data, Chapter A5, Section 5.6.4.B, Low-level mercury. U.S. Geological Survey Techniques of Water-Resources Investigations Report Book 9 U.S. Geological Survey Techniques of Water-Resources Investigations Report Book 9.

32. DeWild JF, Olson ML, Olund SD. Determination of methyl mercury by aqueous phase ethylation, followed by gas chromatographic separation with cold vapor atomic fluorescence detection. Middleton, WI: U. S. Geological Survey. Open-File Report 01-445. 2002;14 p.

33. Method 1631, revision E-mercury in water by oxidation, purge and trap, and cold vapor atomic fluorescence spectrometry. Washington, D.C. U.S. Environmental Protection Agency. EPA-821-R-02-019. 2002;38 p.

34. Aiken GR, McKnight DM, Thorn KA, Thurman EM. Isolation of hydrophilic organic acids from water using nonionic macroporous resins. Organic Geochemistry. 1992;18(4):567-573. doi:10.1016/0146-6380(92)90119-I

35. USGS (variously dated) National field manual for the collection of water-quality data. In: Survey USG, editor. US Geological Survey Techniques of Water-Resources Investigations. Reston, VA: U.S. Geological Survey.

36. Knightes C, Golden H, Journey C, DAvis G, Conrads P, M.E. Brigham, et al. Mercury and methylmercury concentrations in a Coastal Plain watershed: a multi-scale simulation analysis. Environmental Pollution. 2014;187:182-192. doi:10.1016/j.envpol.2013.12.026 